\title{
HUBUNGAN KEYAKINAN AGAMA ISLAM TERHADAP PENERIMAAN VAKSIN MEASLES RUBELLA DI WILAYAH KERJA PUSKESMAS KEMBARAN I BANYUMAS
}

\author{
Havidza Rivani ${ }^{1}$, Yuhantoro Budi Handoyo $S^{2}$, Darodjat ${ }^{3}$, Titik \\ Kusumawinakhyu ${ }^{4}$ \\ ${ }^{1}$ Universitas Muhammadiyah purwokerto, Email : havidzar22@gmail.com \\ ${ }^{2}$ Universitas Muhammadiyah purwokerto \\ 32Universitas Muhammadiyah purwokerto, Email : darodjatjt@gmail.com \\ ${ }^{4}$ Universitas Muhammadiyah purwokerto
}

\begin{abstract}
ABSTRAK
Campak dan Rubella adalah penyakit infeksi yang disebabkan oleh virus campak dan rubella serta dapat menular melalui saluran nafas. Penyakit campak dan rubella bisa dicegah dengan melakukan vaksin MR. Terdapatnya masyarakat yeng terkena campak dan rubella disebabkan penerimaan vaksin yang kurang baik serta beberapa faktor seperti keyakinan agama Islam. Berdasarkan keyakinan agama ibu namun kurang informasi terkait vaksin MR, akan sangat mempengarhui dalam penerimaan vaksin MR. Ibu yang mempunyai informasi terkait vaksin MR, akan melakukan penerimaan vaksin MR. Tujuan penelitian ini yaitu Mengetahui hubungan keyakinan agama islam terhadap penerimaan vaksin Measles Rubella di wilayah kerja Puskesmas 1 Kembaran. Metode yang digunakan Penelitian ini adalah penelitian kuantitatif dan termasuk penelitian observasional analitik dengan pendekatan cross sectional, dengan jumlah sampel sebanyak 100 orang di ambil secara cluster random sampling dan uji hipotesis menggunakan Regresi Linear. Hasil uji Regresi Linear menunjukan nilai Sig.0,000 yang artinya terdapat hubungan keyakinan agama Islam terhadap penerimaan vaksin Measles Rubella. Nilai Coeficient Correlation sebesar 0,469 yang menunjukan korelasi sedang dengan arah korelasi positif antara keyakinan agama Islam terhadap penerimaan vaksin Measles Rubella. Hasil $R$ Square pada penelitian ini yaitu ,220 atau 22\%. Hal ini mengandung arti bahwa kemampuan variabel X dalam menjelaskan variabel $\mathrm{Y}$ adalah sebesar $22 \%$. Masih terdapat $78 \%$ variabel $\mathrm{X}$ lain yang dapat mempengaruhi variabel Y.
\end{abstract}

Kata kunci: Keyakinan; Agama Islam; Penerimaan; Vaksin Measles Rubella.

\begin{abstract}
Measles and Rubella are infectious diseases caused by measles and rubella viruses and can be transmitted through the respiratory tract. Measles and rubella can be prevented by carrying out the MR vaccine. The presence of people affected by measles and rubella is due to poor reception of vaccines and several factors such as Islamic religious beliefs. Based on the religious beliefs of the mother but lack of information regarding the MR vaccine, it will greatly affect the acceptance of the $M R$ vaccine. Mothers who have information related to the MR vaccine, will receive the MR vaccine. The purpose of this study was to determine the correlation of Islamic Religion to the acceptance of Measles Rubella vaccine in the working area of Puskesmas 1 Kembaran. This research was a quantitative research and includes analytic observational research with a cross sectional approach, conducted sample of 100 people taken by cluster random sampling and hypothesis testing using Regresi Linear Test. The results of the Linear Regression test show a Sig. 0.000 value, which means that there is a relationship between Islamic beliefs and acceptance of the Rubella Measles vaccine. The value of Coefficient of correlation is 0.469 which indicates a moderate correlation with the direction of a positive correlation between Islamic religious beliefs towards the receipt of the Rubella Measles vaccine. The results of the $R$ Square in this study were 220 or $22 \%$. This means that the ability of variable $X$ in explaining $Y$ variable is $22 \%$. There are still $78 \%$ of other $X$ variables that can affect the $Y$ variable. There is a significant correlation between Islamic religious beliefs to the acceptance of Measles Rubella vaccine in the working area of Puskesmas 1 Kembaran.
\end{abstract}

Keywords: Belief; Islam; Acceptance; Measles Rubella Vaccine. 


\section{PENDAHULUAN}

Campak dan Rubella adalah penyakit infeksi menular melalui saluran nafas yang disebabkan oleh virus Campak dan Rubella (IDAI, 2017). Campak merupakan penyakit menular yang disebabkan oleh virus genus Morbillivirus (Kutty, et al., 2013). Rubella termasuk dalam penyakit ringan pada anak, tetapi dapat memberikan dampak buruk apabila terjadi pada ibu hamil trimester pertama yaitu keguguran dan kecacatan pada bayi, yang sering disebut Congenital Rubella Syndrom (CRS) seperti kelainan jantung dan mata, ketulian dan keterlambatan perkembangan (Depkes RI, 2017). Menurut WHO (World Health Organization), pada tahun 2000 terdapat 535.000 anak meninggal karena measles. Pada tahun 2008 kejadian Congenital Rubella Syndrom (CRS) terdapat lebih dari 110.000 kasus, dengan kasus tertinggi terdapat di Asia Tenggara yaitu sekitar 48\% dan Afrika sekitar 38\%. WHO melalui Global Alliance for Vaccines and Immunization (GAVI) pada tahun tahun 2012 sampai 2020, merencanakan lewat salah satu programnya adalah mencapai dan mempertahankan tingkat kekebalan masyarakat yang tinggi dengan memberikan dua dosis vaksin yang mengandung campak dan rubella melalui imunisasi rutin dan tambahan dengan cakupan yang tinggi $>95 \%$ dan merata (WHO, 2012).

Data Dinas Kesehatan Jawa Tengah tahun 2012, angka drop out imunisasi di Jawa Tengah adalah sebesar 1,8\%, angka tersebut masih berada di bawah ambang batas yaitu $\leq 5 \%$, dimana drop out rate merupakan persentase bayi yang tidak mendapatkan atau berhenti imunisasi sesuai jadwal (Dinas Kesehatan Provinsi Jawa Tengah, 2012). Profil kesehatan Indonesia tahun 2016 melaporkan 6.890 kasus campak sepanjang tahun 2016, dengan jumlah kematian 5 orang (Ditjen P2P Kemenkes RI, 2017). Pada tahun 2014 sampai 2015 kejadian campak di Indonesia mengalami penurunan yaitu dari 12.943 kasus menjadi 8.185 kasus dengan kejadian tertinggi yaitu pada bayi usia kurang dari 1 tahun. Penurunan kejadian campak tidak menandakan bahwa kejadian penyakit tersebut tidak berbahaya karena sesuai target pemerintah Indonesia pada tahun 2020, Indonesia bebas campak dan rubella dengan angka cakupan imunisasi Measles Rubella (MR) lebih dari 95\%. Cakupan yang tinggi dan merata minimal 95\% akan membentuk herd immunity dan memutus rantai penularan penyakit campak dan rubella (Depkes RI, 2017). Kasus campak di Jawa Tengah pada tahun 2015 didapatkan 576 kasus, meningkat jika dibandingkan dengan tahun 2014 yaitu ditemukan 308 kasus. Meningkatnya kasus tersebut disebabkan belum sepenuhnya masyarakat melakukan vaksin measles rubella (MR) (Dinas Kesehatan Provinsi Jawa Tengah, 2016).

Vaksin MR merupakan vaksin hidup yang sudah dilemahkan dalam bentuk serbuk dan pelarutnya. Vaksin MR dapat diberikan pada anak usia 9 bulan sampai dengan 15 tahun (Ditjen P2P Kemenkes RI, 2017). Cakupan pemberian vaksin MR yang ditargetkan adalah $>95 \%$. Pada masyarakat masih terdapat beberapa kelompok yang kurang menerima dalam pemberian vaksin MR, umumnya mengabaikan 
pencegahan penyakit dan hanya mengutamakan kuratif. Ada beberapa faktor yang menjadi alasan adanya masyarakat tersebut kurang menerima pemberian vaksin diantaranya persepsi keyakinan berdasarkan agama mengenai proses pembuatan vaksin yang mengandung babi dan vaksin tanpa sertifikat halal. Kedua hal tersebut menimbulkan persepsi buruk masyarakat terhadap imunisasi (IDAI, 2015). Faktor yang mempengaruhi rendahnya keinginan melakukan imunisasi adalah rasa keyakinan berdasarkan agama (Holt et al, 2009). Ibu dengan keyakinan agama yang menganggap vaksin sebagai barang haram dan menganggap pembuatan vaksin menggunakan bahan seperti babi, hal tersebut menyebabkan tingkat pemberian vaksin menurun, sehingga mengalihkan sebagian kalangan masyarakat untuk menolak melakukan vaksinasi. Keyakinan agama sangat mempengaruhi terhadap pemberian vaksin (Lorenz \& Khalid, 2012).

Fatwa majelis ulama Indonesia mengungkapkan pendapat Muhammad al-Khatib al-Syarbaini dalam kitab Mughni al-Muhtaj yang menjelaskan bahwa kebolehan menggunakan benda najis atau yang diharamkan untuk obat ketika belum ada benda suci yang dapat menggantikannya. Namun, apabila sudah ditemukan benda suci yang dapat menggantikannya maka pengobatan yang mengandung najis hukumnya menjadi haram (Fatwa MUI, 2016). Berdasarkan survei pendahuluan yang dilakukan di Dinas Kesahatan Banyumas dan Puskesmas 1 Kembaran, masyarakat yang melakukan imunisasi MR setiap tahun mengalami peningkatan, akan tetapi masih terdapat masyarakat khususnya ibu yang tidak menerima untuk melakukan vaksin MR. Tahun 2016 pada Puskesmas 1 Kembaran terdapat 2 kasus campak, terjadinya kasus tersebut karena adanya warga yang tidak melakukan vaksin. Selain itu, hasil wawancara dengan ibu di Puskesmas 1 Kembaran masih terdapat ibu yang belum sepenuhnya menerima vaksin MR. Masyarakat di wilayah kerja Puskesmas Kembaran I masih banyak yang percaya bahwa vaksin measles rubella adalah vaksin yang haram karena kandungan vaksin tersebut terbuat dari enzim binatang babi.

\section{TINJAUAN TEORITIS}

Campak merupakan suatu penyakit infeksi yang sangat menular dan disebabkan oleh virus, pada umumnya penyakit campak menyerang anak-anak serta merupakan penyakit endemis di seluruh dunia (Budi, 2012). Gejala klinis campak berupa demam, batuk, konjungtivitis dan ruam kulit. Cara penularan dengan droplet dan kontak langsung (Behrman, 2012). Penyakit campak bersifat endemik di seluruh dunia, pada tahun 2013 terjadi 145.700 kematian yang disebabkan oleh campak di seluruh dunia atau berkisar 400 kematian setiap hari dan terjadi pada sebagian besar anak kurang dari 5 tahun (WHO, 2015). Indonesia masih terdapat banyak kasus campak dengan jumlah kasus yang dilaporkan mencapai 12.222 kasus. Frekuensi Kejadian Luar Biasa (KLB) sebanyak 173 kejadian dengan 2.104 kasus. Sebagian besar kasus campak adalah anak-anak usia pra-sekolah dan usia SD. Selama periode 4 tahun, kasus campak lebih banyak terjadi pada kelompok umur 5-9 tahun sebanyak 
3.591 kasus dan pada kelompok umur 1-4 tahun sebanyak 3.383 kasus (Ditjen P2P Kemenkes RI, 2017).

Manusia adalah satu-satunya hospes alamiah rubella, yang disebarkan oleh droplet oral atau secara transplasenta melalui infeksi congenital. Rubella terdistribusi secara luas di seluruh dunia. Sebelum pembentukan program vaksin rubella pada tahun 1969, puncak insiden penyakit terjadi pada anak usia 5-14 tahun (Behrman, 2012). Sebelum dilakukan vaksin rubella, insidens CRS bervariasi antara 0,1-0,2/1000 kelahiran hidup pada periode endemik dan antara 0,8-4/1000 kelahiran hidup selama periode epidemi rubella. Angka kejadian CRS pada negara yang belum mengintroduksi vaksin rubella diperkirakan cukup tinggi. Pada tahun 1996 diperkirakan sekitar 22.000 anak lahir dengan CRS di regio Afrika, sekitar 46.000 di regio Asia Tenggara dan 12.634 di regio Pasifik Barat. Insiden CRS pada regio yang telah mengintroduksi vaksin rubella selama tahun 1996-2008 telah menurun. Pada tahun 2010 sampai 2015, diperkirakan terdapat 30.463 kasus rubella (Ditjen P2P Kemenkes RI, 2017). Penyebab rubella adalah togavirus jenis rubivirus dan termasuk golongan virus RNA. Virus rubella cepat mati oleh sinar ultra violet, bahan kimia, bahan asam dan pemanasan. Virus tersebut dapat melalui sawar plasenta sehingga menginfeksi janin dan dapat mengakibatkan abortus atau congenital rubella syndrome (CRS) (James, 2000).

Imunisasi adalah proses menginduksi imunitas secara buatan, imunisasi terdapat dua macam yaitu imunisasi aktif dan imunisasi pasif (Depkes RI, 2010). Imunisasi aktif menstimulasi sistem imun untuk membentuk antibodi dan respon imun seluler yang melawan agen penginfeksi. Imunisasi pasif merupakan proteksi sementara melalui pemberian antibodi yang di produksi secara eksogen dan transmisi transplasenta dari ibu ke janin (Notoatmodjo, 2012). Manfaat utama dari imunisasi adalah menurunkan angka kejadian penyakit, kecacatan, dan kematian akibat penyakit-penyakit infeksi yang dapat dicegah dengan imunisasi (Ranuh, 2011). Imunisasi tidak hanya memberikan perlindungan pada individu akan tetapi juga komunitas, terutama untuk penyakit yang di tularkan melalui manusia (person-to-person). Komunitas yang memiliki angka cakupan imunisasi tinggi, komunitas tersebut memiliki imunitas yang tinggi. Hal ini menanandakan terjadinya penyakit yang dapat dicegah dengan imunisasi (vaccine preventable disease) rendah. Anak yang belum atau tidak mendapatkan imunisasi karena alasan tertentu memiliki resiko terjangkit penyakit lebih tinggi daripada anak-anak yang mendapat imunisasi (Hidayat, B. 2011)

Imunisasi juga bermanfaat mencegah penyakit pada generasi mendatang. Cakupan Imunisasi yang rendah pada generasi sekarang dapat menyebabkan penyakit semakin meluas pada generasi yang akan datang dan dapat menyebabkan epidemi. Sebaliknya, jika cakupan imunisasi tinggi, penyakit akan dapat dihilangkan dari dunia. Hal ini sudah dibuktikan dengan dihilangkannya penyakit cacar (smallpox) 
(Wahab, 2002). Manfaat lain imunisasi adalah menghemat biaya kesehatan dengan menurunya angka kejadian penyakit biaya kesehatan yang digunakan untuk mengobati penyakit- penyakit tersebut akan berkurang (Satgas Imunisasi IDAI, 2011).

Vaksin adalah suatu bahan yang berasal dari virus atau bakteri yang menjadi penyebab penyakit bersangkuan yang telah dilemahkan dan dimatikan dari virus atau bakteri penyebab penyakit, yang secara sengaja dimasukkan ke dalam tubuh seseorang dengan tujuan merangsang timbulnya zat anti penyakit tertentu pada orang tersebut (IDAI, 2011). Pemberian vaksin akan merangsang tubuh untuk merangsang antibodi. Vaksin merupakan kumpulan molekul yang kompleks, mengandung substansi imun yang mampu mempengaruhi imunitas spesifik, aktif, dan protektif seseorang untuk melawan penyakit menular (Atika, 2010).

Vaksin Measles Rubella (MR) adalah vaksin hidup yang dilemahkan (live attenuated) berupa serbuk kering dengan pelarut. Kemasan vaksin adalah 10 dosis per vial (Ditjen P2P Kemenkes RI, 2017). Vaksin MR diberikan secara subkutan dengan dosis $0,5 \mathrm{ml}$. Vaksin hanya boleh dilarutkan dengan pelarut yang disediakan dari produsen yang sama. Vaksin yang telah dilarutkan harus segera digunakan paling lambat selama 6 jam setelah dilarutkan. Pemberian imunisasi ditunda pada keadaan demam, batuk pilek dan diare (Ditjen P2P Kemenkes RI, 2017). Vaksin Measles Rubella (MR) adalah vaksin yang aman saat diberikan, namun seperti sifat setiap obat memiliki reaksi efek samping. Reaksi efek samping yang bisa saja terjadi adalah reaksi lokal seperti nyeri, bengkak dan kemerahan di lokasi suntikan dan reaksi sistemik berupa ruam atau rash, demam, dan malaise dan reaksi samping tersebut akan sembuh dengan sendirinya (Ditjen P2P Kemenkes RI, 2017).

Islam menunjukan pengertian umum yang mendasar dan lengkap, serta menuju kepada yang satu, yaitu penyerahan diri atau pasrah kepada Tuhan dengan bentuk dan realisasinya. Dengan demikian Islam adalah sikap hidup yang mencerminkan sikap hidup penyerahan diri ketundukan, kepasrahan, dan kepatuhan kepada Tuhan. Dengan sikap yang demikian akan dapat mewujudkan kedamaian, keselamatan, kesejahteraan, serta kesempurnaan hidup lahir batin dunia akhirat (Muhaimin et al, 2005). Dengan kemampuan dan intelektual semata, manusia tidak mampu memahami sepenuhnya `hukum-hukum Allah yang berlaku secara universal di alam ini, yang merupakan batasan-batasan bagi kebebasannya. Untuk itu Allah SWT mengutus Rasul-rasulnya, guna menyampaikan petunjuk bagaimana seharusnya manusia hidup di alam atau dunia ini, dan bagaimana manusia menggunakan kebebasannya dalam batas-batas yang aman, demi terwujudnyakehidupan yang selamat, aman, dan sejahtera. Petunjuk dan pedoman hidup yang berasal dari Allah SWT dan disampaikan melalui rasul-rasulnya yang disebut dengan Islam atau agama Islam (Muhaimin et al, 2005).

Allah telah mengutus para Rasul-Nya secara silih berganti, sepanjang sejarah, 
dengan membawa ajaran Islam untuk disampaikan kepada umatnya masing-masing. Di antara para Rasul itu terdapat hubungan fungsional satu sama lain, yaitu para rasul yang datang kemudian berfungsi untuk menyempurnakan dan meluruskan ajaran Islam yang dibawa oleh Rasul sebelumnya. Fungsi menyempurnakan berkaitan dengan keadaan ajaran Islam terdahulu yang sudah tidak relevan dengan keadaan masyarakat dan perubahan serta perkembangan zaman (Muhaimin et al, 2005). Nabi Muhammad SAW telah membakukan ajaran agama Islam secara sempurna, sehingga akan terjamin autentitas sekaligus perkembangannya sesuai dengan tuntutan perkembangan zaman dan tempat. Sistem pembakuan ajaran Islam adalah sebagai berikut (Muhaimin et al, 2005): pertama, membukukan secara autentik sumber dasar pokok-pokok dan prinsip- prinsip ajaran Islam sebagai wahyu dari Allah yang tertuang dalam Al-Qur'an. Kedua, memberikan penjelasan contoh dan teladan pelaksanaan ajaran Islam secara operasional, dalam kehidupan sosialbudaya umatnya. Ketiga, memberikan cara atau metode untuk mengembangkan ajaran Islam secara terpadu dalam kehidupan sosial-budaya umat manusia sepanjang sejarah dengan sistem ijtihad. Dengan sistem tersebut, maka ajaran Islam akan tetap bersifat autentik sempurna dan bersifat dinamis, yakni sesuai dengan tuntutan perkembangan zaman dan tempat.

Al-Qur'an adalah kumpulan autentik dari firman-firman Allah SWT yang disampaikan kepada Nabi Muhammad SAW melalui malaikat Jibril, yang tertulis dengan bahasa Arab, sebagai sumber dasar ajaran Islam. Sebagai kumpulan autentik firman Allah, Al-Qur'an akan tetap autentik sepanjang zaman, dan inilah yang akan menjamin bahwa ajaran Islam akan tetap sempurna dan lurus. As-Sunnah adalah tradisi, kebiasaan dan praktik-praktik pelaksanaan ajaran Islam yang dilaksanakan, ditetapkan dan direncanakan oleh Nabi Muhammad, sebagai penjelasan secara operasional serta contoh teladan pelaksanaan dari firman Allah SWT sebagaimana termaktub dalam ajaran Al-Qur'an. As-Sunnah ini kemudian dibukukan dalam kitab-kitab Hadits. Oleh karena itu bersama Al-Qur'an, As-Sunnah juga merupakan sumber autentik dari ajaran Islam (Muhaimin et al, 2005).

Menurut fatwa MUI nomor 4 tahun 2016 diputuskan bahwa imunisasi pada dasarnya dibolehkan (mubah) sebagai bentuk ikhtiar untuk mewujudkan kekebalan tubuh (imunitas) dan mencegah terjadinya suatu penyakit tertentu. Hal ini didasarkan pada Al-Qur'an Surat Al-Baqarah :173: sesungguhnya Allah hanya mengharamkan bagimu bangkai, darah, daging babi, dan binatang yang disebut (nama) selain Allah. Tetapi barangsiapa dalam keadaan terpaksa (memakannya) sedang dia tidak menginginkannya dan tidak (pula) melampaui batas, maka tidak ada dosa baginya. Sesungguhnya Allah Maha Pengampun lagi Maha Penyayang.

Terkait dengan vaksin, MUI mengeluarkan fatwa bahwa vaksin yang haram/najis tidak diperbolehkan, kecuali: pertama, digunakan pada kondisi al-hajat (darurat). Kedua, belum ditemukan bahan vaksin yang halal dan suci. Ketiga, adanya 
keterangan tenaga medis yang kompeten dan dipercaya bahwa tidak ada vaksin yang halal. Dalam hal jika seseorang yang tidak diimunisasi akan menyebabkan kematian, penyakit berat, atau kecacatan permanen yang mengancam jiwa, berdasarkan pertimbangan ahli yang kompeten dan dipercaya, maka imunisasi hukumnya wajib (Fatwa MUI, 2016)

\section{METODE PENELITIAN}

Jenis penelitian ini adalah penelitian kuantitatif dan termasuk penelitian observasional analitik dengan pendekatan cross sectional. Cross sectional merupakan metode penelitian yang dilakukan dengan mengambil waktu tertentu yang cukup pendek dengan status eksposur (paparan) dan status penyakit yang diukur pada waktu yang bersamaan pada suatu populasi. Penelitian dilakukan dengan cara pengisian kuesioner. Analsisi statistik ini menggunakan uji Regresi Linear yang bertujuan untuk mengetahui ada dan tidaknya suatu hubungan. Setelah itu, akan dilakukan uji Pearson untuk mengetahui seberapa kuat hubungan tersebut. Populasi pada penelitian ini adalah masyarakat yang ber agama Islam dan tinggal di wilayah kerja Puskesmas 1 Kembaran, Kecamatan Kembaran, Kabupaten Banyumas. Sampel adalah obyek yang diteliti dan dianggap mewakili seluruh populasi (Notoatmodjo, 2012). Sampel yang digunakan dalam penelitian ini adalah ibu-ibu yang beragama Islam dan tinggal di wilayah kerja Puskesmas 1 Kembaran, Kecamatan Kembaran, Kabupaten Banyumas.

\section{Besar Sampel}

Cara menentukan besar sampel dalam penelitian ini adalah dengan menggunakan rumus Slovin, hal tersebut dikarenakan jumlah ukuran populasi dalam penelitian ini sudah diketahui dengan pasti. Dengan rumus:

$$
n=\frac{N}{1+N\left(e^{2}\right)}
$$

Keterangan:

$\mathrm{n}=$ ukuran sampel

$\mathrm{N}=$ Jumlah Populasi

$\mathrm{e}=$ Tingkat Kesalahan

Populasi berjumlah 15.348 ibu-ibu dan tingkat kesalahan yang digunakan sebesar $10 \%(0,1)$ atau dapat dikatakan tingkat keakuratannya sebesar $90 \%(0,9)$, maka sampel yang diambil untuk mewakili populasi tersebut yaitu sebesar:

$$
\begin{aligned}
& n=\frac{N}{1+N\left(e^{2}\right)} \\
& n=\frac{15348}{1+15348\left(0,1^{2}\right)} \\
& n=\frac{15348}{154,48}=99,35
\end{aligned}
$$

Berdasarkan hasil perhitungan di atas maka sampel penelitian ini dibulatkan menjadi 100 responden. 


\section{Teknik Pengambilan Sampel}

Teknik sampling yang digunakan dalam penelitian ini menggunakan cluster random sampling yaitu pengambilan sampel secara acak berkelompok. Pengambilan sampel tersebut berdasarkan kriteria inklusi dan eksklusi yang sudah ditetapkan oleh peneliti.

\section{HASIL}

\section{Analisis Univariat}

Penelitian tentang hubungan pengetahuan dan sikap ibu terhadap penerimaan vaksin meassles rubella (MR) ini dilakukan di wilayah kerja Puskesmas I Kembaran yang berada di wilayah Kecamatan Kembaran, Kabupaten Banyumas. Penelitian dilakukan pada hari Kamis, tanggal 16 Agustus 2018. Wilayah kecamatan Kembaran memiliki luas wilayah 25,92 km2 dan berada pada ketinggian 73,6 m dari permukaan laut dengan curah hujan $2.834 \mathrm{~mm}$ per tahun.

Gambar 1: Distribusi Usia Responden di Wilayah Kerja Puskesmas 1 Kembaran Kabupaten Banyumas

Berdasarkan hasil penelitian yang tersaji dalam gambar 1 dapat diketahui bahwa sebagian besar usia responden penelitian berada pada rentang 31-40 tahun yaitu sebanyak 44 orang (44\%), sedangkan responden yang berusia 20-30 tahun sebanyak 43 orang $(43 \%)$ dan responden yang berusia $>40$ tahun sebanyak 13 orang (13\%).

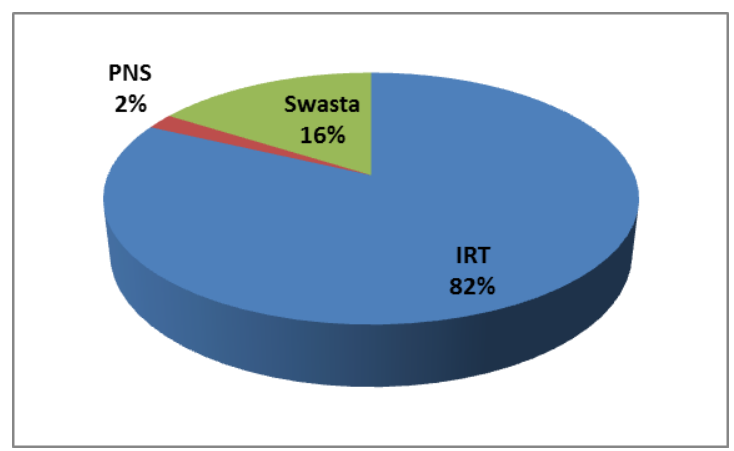

Gambar 2: Distribusi Pekerjaan Responden di Wilayah Kerja Puskesmas 1 Kembaran Kabupaten Banyumas

Hasil penelitian yang tersaji dalam gambar 2 di atas dapat diketahui bahwa sebagaian besar responden penelitian berprofesi sebagai ibu rumah tangga (IRT) yaitu sebanyak 82 orang (82\%) sedangkan yang berprofesi sebagai swasta sebanyak 
16 orang (16\%) dan PNS sebanyak 2 orang $(2 \%)$.

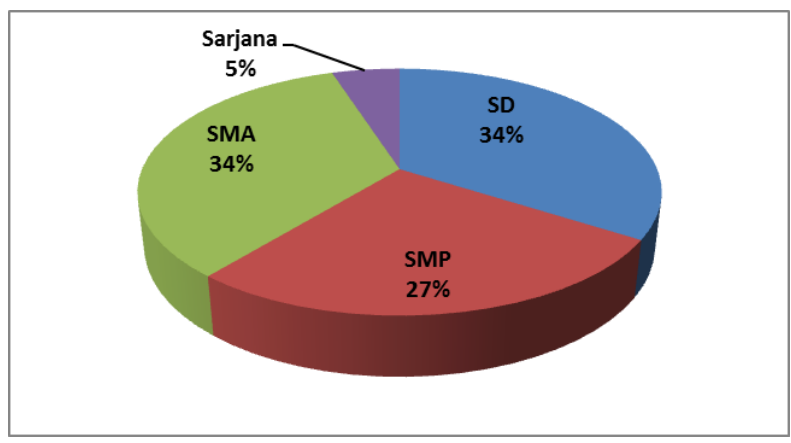

Gambar 3: Distribusi Pendidikan Responden di Wilayah Kerja Puskesmas 1

Kembaran Kabupaten Banyumas

Distribusi frekuensi tingkat pendidikan responden yang tersaji dalam gambar 3 dapat diketahui bahwa mayoritas responden yang memiliki pendidikan SD dan SMA yaitu sama-sama sebanyak 34 orang (34\%) sedangkan yang tamatan SMP sebanyak 27 orang $(27 \%)$ dan lulusan Sarjana sebanyak 5 orang (5\%).

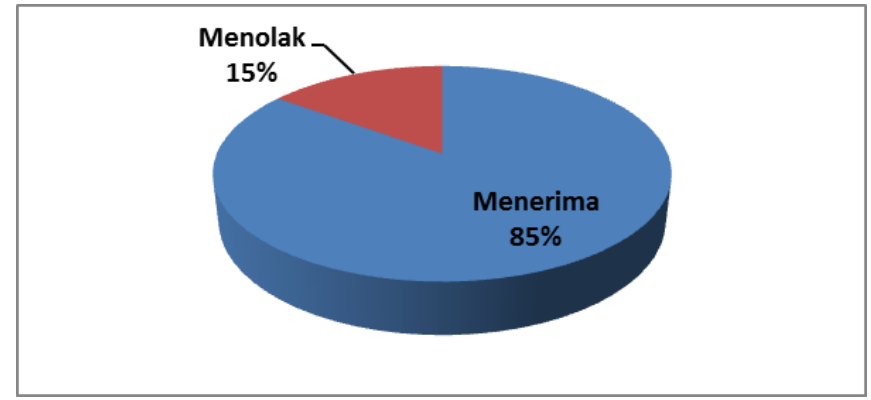

\section{Gambar 4: Distribusi Penerimaan Vaksin MR di Wilayah Kerja Puskesmas 1 Kembaran Kabupaten Banyumas}

Berdasarkan perhitungan menggunakan data yang didapat saat penelitian mengenai penerimaan vaksin MR yang tersaji pada tabel 4 dapat diketahui bahwa mayoritas responden penelitian menerima vaksin MR yaitu sebanyak 85 orang $(85 \%)$ sedangakan yang menolak sebanyak 15 orang (15\%). Penolakan vaksin bisa dipengaruhi oleh 3 hal faktor predisposisi menurut Lawrance Green dalam Notoatmodjo (2012) yaitu Pengetahuan, Sikap, Keyakinan agama. Pengetahun seseorang akan vaksin sangat berperan dalam penerimaan vaksin sehingga pengetahuan sangat menentukan apakah seseorang tersebut menerima atau menolak terhadap vaksin.

Sikap seseorang dalam menerima vaksin juga sangat menentukan peneriman vaksin. Pengetahuan yang kurang akan menentukan sikap seseorang dalam menilai vaksin yang kurang baik. Keyakinan Agama juga sangat berpengaruh terhadap penerimaan vaksin karena keyakinan berhubungan dengan spiritual seseorang. Kepercayaan seseorang akan bahan pembuatan vaksin dapat mempengaruhi penerimaan vaksin. 
Uji Hipotesis adalah metode pengambilan keputusan yang didasarkan dari analisis data, baik dari percobaan yang terkontrol, maupun dari observasi (tidak terkontrol). Pada penelitian ini dilakukan uji hipotesis menggunakan uji Regresi Linear. Uji Regresi Linear merupakan uji yang digunakan untuk mengukur besarnya pengaruh satu variabel bebas atau variabel independent atau variabel $\mathrm{X}$ terhadap variabel tergantung atau variabel dependen atau variabel terikat. Hasil uji regresi linear sebagai berikut:

Tabel 1: Uji Regresi Linear

\begin{tabular}{|c|c|c|c|c|c|}
\hline $\begin{array}{c}\text { Variabel } \\
\text { Independen }\end{array}$ & $\begin{array}{l}\text { Variabel } \\
\text { dependen }\end{array}$ & Sig. & $\begin{array}{c}\text { Derajat } \\
\text { hubungan }\end{array}$ & $\begin{array}{c}\text { Koefisien } \\
\text { korelasi }\end{array}$ & Keterangan \\
\hline $\begin{array}{l}\text { Keyakinan } \\
\text { Agama } \\
\text { Islam }\end{array}$ & $\begin{array}{c}\text { Penerimaan } \\
\text { Vaksin } \\
\text { Measles } \\
\text { Rubella } \\
\end{array}$ & $\begin{array}{c}0,00 \\
0\end{array}$ & $\begin{array}{l}\text { Korelasi } \\
\text { sedang }\end{array}$ & 0,469 & Berkorelasi \\
\hline
\end{tabular}

Berdasarkan table 1 didapatkan nilai sig. 0,000 sehingga dinyatakan terdapat hubungan antara Keyakinan Agama Islam terhadap Penerimaan Vaksin Measles Rubella. Nilai Coeficient Correlation sebesar 0,469 yang menunjukkan korelasi sedang dengan arah korelasi positif antara Keyakinan Agama Islam terhadap Penerimaan Vaksin Measles Rubella.

Uji korelasi Pearson merupakan suatu uji yang digunakan untuk mencari hubungan antara dua variabel, yaitu variabel bebas atau independent variable dan variabel terikat atau dependent variable.

Tabel 2 : Uji Pearson

\begin{tabular}{lccc}
\hline \multicolumn{1}{c}{ Variabel } & Sig. & $\begin{array}{c}\text { Coefficient } \\
\text { Correlation }\end{array}$ & keterangan \\
\hline $\begin{array}{l}\text { Keyakinan } \\
\text { Agama Islam }\end{array}$ & 0,000 & 0,469 & Berkorelasi \\
$\begin{array}{l}\text { Penerimaan } \\
\text { Vaksin Measles } \\
\text { Rubella }\end{array}$ & & & \\
\hline
\end{tabular}

Berdasarkan tabel 2 didapatkan nilai sig. 0,000 sehingga dinyatakan terdapat hubungan antara Keyakinan Agama Islam terhadap Penerimaan vaksin Measles Rubella. Nilai Coeficient Correlation sebesar 0,469 yang menunjukkan korelasi sedang dengan arah korelasi positif antara Keyakinan Agama Islam terhadap Penerimaan Vaksin Measles Rubella.

Hasil penelitian ini adalah terdapat hubungan keyakinan Agama Islam terhadap penerimaan vaksin measles rubella. Korelasi antara kedua variabel tersebut didukung oleh hasil $R$ Square. Nilai R Square dapat menentukan seberapa besar sumbangan nilai Keyakinan Agam Islam terhadap penerimaan vaksin. 
Tebel 3 : Model Summary

\begin{tabular}{|l|r|r|r|r|}
\hline Model & $\mathrm{R}$ & $\mathrm{R}$ Square & $\begin{array}{c}\text { Adjusted R } \\
\text { Square }\end{array}$ & $\begin{array}{c}\text { Std. Error of } \\
\text { the Estimate }\end{array}$ \\
\hline 1 &, $469^{\mathrm{a}}$ &, 220 &, 212 & 3,960 \\
\hline
\end{tabular}

a. Predictors: (Constant), Keyakinan Agama

$R$ Square sebesar 0,220 atau 22\%. Hal ini mengandung arti bahwa kemampuan variabel $\mathrm{X}$ dalam menjelaskan variabel $\mathrm{Y}$ adalah sebesar 22\%. Artinya masih terdapat $78 \%$ variabel $\mathrm{X}$ yang lain yang bisa mempengaruhi variabel $\mathrm{Y}$.

\section{PEMBAHASAN}

Hasil penelitian ini sejalan dengan penelitian yang dilakukan oleh Rachmawati Sukarno Putri (2016) yang bertujuan untuk mengetahui faktor-faktor yang mempengaruhi kepatuhan ibu dalam pemberian imunisasi dasar balita menunjukan hasil bahwa terdapat $59 \mathrm{ibu}$ yang menolak dari total $87 \mathrm{ibu}$ yang beragama Islam dalam pemberian imunisasi (67,8\%). Penelitian yang dilakukan Pratiwi Sulistiyani et al (2017) bertujuan untuk mengetahui gambaran penolakan masyarakat terhadap imunisasi. Dari hasil penelitian ditemukan bahwa 7 dari 11 subjek menolak adanya pemberian imunisasi dikarenakan subjek tersebut percaya bahwa vaksin tersebut terbuat dari babi dan bersifat haram. Penelitian ini sejalan dengan hasil yang ditemukan oleh Pratiwi Sulistiyani.

Penelitian ini juga sejalan dengan penelitian yang dilakukan oleh Meidiana Dwidiyanti (2017) menemukan hasil terdapat 6 subjek ibu yang menolak adanya pemberian vaksin. Banyak faktor yang dapat mempengaruhi penerimaan vaksin salah satunya adalah keyakinan dan persepsi yang dipandang dari agama pasien. Dari penelitian tersebut subjek mengaku bahwa vaksin itu sangatlah haram karena terbuat dari babi dan akan sangat berbahaya apabila diberikan pada anak balitanya. Hal ini sangat berbanding terbalik dengan teori yang diungkapkan oleh Hidayat (2008) bahwa dengan pemberian vaksin dapat meningkatkan kekebalan tubuh terhadap penyakit tertentu. Melakukan vaksinasi merupakan suatu upaya untuk melakukan pencegahan suatu penyakit tertentu. Pengetahuan dan keyakinan seseorang sangatlah mempengaruhi. Seperti penelitian yang dilakukan oleh Agnes Widyani Palupi (2011) melakukan pemberian penyuluhan untuk ibu agar melakukan vaksinasi sangatlah penting untuk meningkatkan pengetahuan dan keyakinan ibu akan pentingnya melakukan vaksinasi. Hasil penelitian yang dilakukan oleh Agnes Widyani Palupi mendapatkan bahwa semua ibu melakukan vaksinasi karena sebelumnya sudah diberikan penyuluhan oleh tenaga kesehatan setempat.

Vaksim MR (Measles Rubella) merupakan vaksin hidup yang sudah dilemahkan dalam bentuk serbuk. Vaksin MR diberikan dengan tujuan untuk 
meningkatkan kekebalan tubuh agar terhindar dari penyakit Rubella. Vaksin MR diberikan dengan dosis $0,5 \mathrm{ml}$ paling lambat 6 jam setelah dicairkan. Vaksin MR diberikan pada usia 9 bulan sampai usia kurang dari 15 tahun (Ditjen P2P Kemenkes RI, 2017). Vaksin MR mengandung enzim babi. Enzim babi ini merupakan katalisator dari penyempurnan vaksin. Ketika vaksin sudah dinyatakan sempurna dan bisa digunakan, maka katalisator (enzim babi) akan hilang. Apabila vaksin tidak sempurna, maka enzim babi belum dikatakan hilang dari vaksin tersebut. Fatwa MUI memperbolehkan dalam penerimaan vaksin MR sebagai pencegah penyakit yang spesifik. Vaksin MR mengandung enzim babi. Enzim babi ini merupakan katalisator dari penyempurnan vaksin. Ketika vaksin sudah dinyatakan sempurna dan bisa digunakan, maka katalisator (enzim babi) akan hilang. Apabila vaksin tidak sempurna, maka enzim babi belum dikatakan hilang dari vaksin tersebut. Fatwa MUI memperbolehkan dalam penerimaan vaksin MR sebagai pencegah penyakit yang spesifik.

Hasil penelitian ini tidak sejalan dengan apa yang dikeluarkan oleh fatwa MUI (2016) yang menyatakan bahwa boleh menggunakan benda najis sebagai pengobatan apabila tidak ditemukan benda suci sebagai bahan pengobatan. Namun, apabila ditemukan benda suci sebagai bahan pengobat maka vaksin yang terbuat dari benda najis akan diharamkan. Dari beberapa hasil penelitian diatas dan hasil penelitian ini dapat memberikan sedikit gambaran bahwa keyakinan agama Islam masih mempengaruhi terhadap penerimaan vaksin. Masyarakat masih beranggapan bahwa vaksin adalah benda haram dan tidak boleh digunakan untuk kesehatan. Hal ini bisa disebabkan karena minimnya pemberian informasi kepada masyarakat bahwa vaksin bersifat mubah (diperbolehkan) dalam Islam sebagai bentuk untuk meningkatkan kekebalan tubuh agar tercegah dari penyakit tertentu.

Menurut Fitriani (2015) mengemukakan bahwa penerimaan vaksin juga dapat dipengaruhi oleh beberapa faktor seperti usia, pekerjaan, pendidikan, media massa sosial budaya, dan status ekonomi, lingkungan. Pendidikan merupakan sebuah usaha untuk mengembangkan kepribadian serta kemampuan didalam dan diluar sekolah yang berlangsung seumur hidup. Pendidikan dapat mempengaruhi seseorang termasuk juga perilaku seseorang akan pola hidup terutama dalam memotivasi untuk bersikap. Pada umumnya semakin tinggi pendidikan seseorang makin mudah menerima informasi. Pengetahuan seseorang tentang suatu objek mengandung dua aspek yaitu aspek positif dan aspek negatif. Kedua aspek ini dapat menentukan sikap seseorang terhadap objek tersebut. Semakin banyak aspek positif dari objek yang diketahui dapat menumbuhkan sikap positif terhadap objek tersebut.

Pekerjaan merupakan kebutuhan yang harus dilakuakan terutama untuk menunjang kehidupan. Lingkungan pekerjaan dapat menjadikan seseorang memperoleh pengalaman dan pengetahuan baik secara langsung dan tidak langsung. Pada seseoarang yang tidak bekerja terutama ibu jika tidak bekerja dapat 
memberikan imunisasi lengkap lebih baik dari pada ibu yang bekerja, dikarenakan ibu yang bekerja tidak mempunyai waktu dan sibuk.

Kemajuan teknologi memiliki bermacam-macam media massa yang dapat mempengaruhi pengetahuan masyarakat tentang informasi baru. Sarana komunikasi seperti radio, televisi, surat kabar, majalah dan penyuluhan mempunyai pengaruh besar terhadap pembentukan opini dan kepercayaan orang. Paparan media secara signifikan berhubungan dengan imunisasi. Hal ini dapat dikaitkan dengan pesan yang diterima orang tua melalui media dan membuat anak mereka diimuisasi. Status ekonomi seseorang dapat menentukan ketersediaan fasilitas yang diperlukan untuk kegiatan tertentu, sehingga status sosial ekonomi akan mempengaruhi pengetahuan seseorang. Pada kebudayaan setempat dan kebiasaan dalam keluarga juga dapat mempengaruhi pengetahuan, presepsi dan sikap seseorang. Usia akan mempengaruhi daya tangkap dan pola pikir seseorang. Bertambahnya usia akan mengembangkan pola pikir dan daya tangkap seseorang sehingga pengetahuan yang diperoleh akan semakin banyak. Lingkungan merupakan sesuatu yang ada di sekitar individu seperti lingkungan fisik, biologis dan sosial. Lingkungan berpengaruh terhadap proses masuknya pengetahuan ke dalam individu yang berada pada lingkungan tersebut. Hal tersebut terjadi karena adanya interaksi timbal balik yang akan direspon sebagai pengetahuan

\section{SIMPULAN}

Penelitian ini bertujuan untu mengetahui hubungan keyakinan agama Islam terhadap penerimaan vaksin measles rubella. Pengolahan data ini menggunakan uji Reagresi Linear untuk mengetahui suatu hubungan antara variabel $\mathrm{X}$ terhadap variabel Y. Kekuatan hubungan antara variabel X terhadap variabel Y dilakukan uji Pearson. Berdasarkan hasil yang telah dilakukan mengenai hubungan keyakinan agama Islam terhadap penerimaan vaksin Measles Rubella di wilayah kerja Puskesmas Kembaran 1 yaitu Terdapat hubungan yang positif dengan nilai Coeficient Correlation yaitu 0,469 yang berarti kekuatan sedang antara keyakinan agama Islam terhadap penerimaan vaksin Measles Rubella di wilayah kerja Puskesmas 1 Kembaran.

Keyakinan Agama Islam memberikan pengaruh terhadap variabel terikat sebesar 22\%. Penerimaan vaksin MR di wilayah kerja Puskesmas 1 kembaran masih terdapat penolakan. Dari 100 responden, terdapat 15 orang yang menolak melakukan penerimaan vaksin. Pendidikan dan pekerjaan juga dapat mempengaruhi adanya penerimaan vaksin Measles Rubella. Pendidikan adalah proses seseorang mengembangkan kemampuan, sikap, dan bentuk-bentuk tingkah laku manusia di dalam masyarakat tempat ia hidup, proses sosial, yakni orang dihadapkan pada pengaruh lingkungan yang terpilih dan terkontrol (khususnya yang datang dari sekolah), sehingga dia dapat memperoleh atau mengalami perkembangan kemampuan sosial, dan kemampuan individu yang optimal. 


\section{DAFTAR PUSTAKA}

Agnes Widyani Palupi. (2011). Pengaruh Penyuluhan Imunisasi Terhadap Peningkatan Pengetahuan dan Sikap Ibu Tentang Imunisasi Dasar Lengkap Pada Bayi Sebelum Usia 1 Tahun. Program Pasca Sarjana. Universitas Sebelas Maret, Surakarta.

Atika. (2010). Imunisasi dan Vaksinasi Bantul.Yogyakarta Nuha Medika. Lelyana Martha Damarstuti, dkk. 2007. Analisis Variabel Antecedents bagi Keyakinan Diri (selfefficacy) Yang Berpengaruh Pada Motivasi Pra Pelatihan (Studi Guru Di SMA Negeri Se-Kota Semarang).

Behrman RE., Kliegman RM., Arvin AM. (2012). Nelson Ilmu Kesehatan Anak: "Infeksi Virus-Rubella" (Edisi ke-15). Terjemahan Oleh: Maldonado, Y., EGC, Jakarta, Indonesia, hal. 1072.

Depkes RI (2017) Pedoman Pengelolaan Vaksin Jakarta: Dirjen Bina Farmasi dan Alat Kesehatan.

Ditjen P2P. (2017). Petunjuk Teknis Kampanye Imunisasi Measles Rubella (MR). Kementrian Kesehatan Republik Indonesia.

Dinas Kesehatan Jawa Tengah. (2016). Profil Kesehatan Provinsi Jawa Tengah Tahun 2015. Semarang, Pusat Data dan Informasi Dinas Kesehatan.

Dinas Kesehatan Jawa Tengah. (2012). Profil Kesehatan Provinsi Jawa Tengah Tahun 2012. Semarang, Pusat Data dan Informasi Dinas Kesehatan.

Fatwa Majelis Ulama Indonesia. 2016. Fatwa Tentang Penyelenggaraan Imunisasi. Bogor.

Hidayat, B., Pujiarto, P. S., dan Gunardi, H. (2011). Hepatitis B Di dalam: I. G. N. Ranuh (ed.) Pedoman Imunisasi di Indonesia, Edisi Keempat. Jakarta: Badan Penerbit Ikatan Dokter Anak Indonesia, pp. 25-37.

Holt CL, Clark EM, et al. 2009. Depelovment and Validation of Instruments to Assess Potential Religion-Health Mechanism in an African American Population. Journal of Black Phsychology; 35(2): pp 271-288.

IDAI, 2017. Imunisasi Campak - Rubella (MR). [Online]. Available at: http: // www.idai.or.id/artikel/klinik/imunisasi/imunisasi-campak-rubella-mr [Accessed 10 Juni 2018]

IDAI, (2015). Menyoroti Kontroversi Seputar Imunisasi. Jakarta: Badan Penerbit IDAI.

IDAI (2011). Pedoman Imunisasi di Indonesia. Edisi Keempat. Jakarta: Badan Penerbit IDAI.

James C. (2000). Rubella. Dalam: Kandun, I.N (Editor). Manual Pemberantasan Penyakit Menular (hal. 453 - 456). Balai Penerbit FKUI, Jakarta, Indonesia.

Kemenkes RI. (2016). Profil Kesehatan Indonesia 2015. Jakarta: Kementrian Kesehatan RI.

Kutty, P. et al., (2013). Measles. VP D Surveillance Manual, Volume 6.

Lorenz C, Khalid M. 2012. Influencing Faktor on Vaccation Uptake in Pakistan. Journal of Pakistan Medical Association.

Meidiana Dwidiyanti. (2017). Pengetahuan dan Persepsi Ibu yang Menolak Pemberian Imunisasi. Vol 4, No.1. Universitas Diponegoro. Indonesia.

Notoatmodjo, S. (2012). Ilmu Perilaku Kesehatan. Jakarta: Rineka Cipta.

Pratiwi Sulistiyani, et al. (2017). Gambaran Penolakan Masyarakat Terhadap Imunisasi Dasar Lengkap Bagi Balita. Fakultas Kesehatan Masyarakat. 
Universitas Diponegoro, Semarang.

Rachmawati Sukarno Putri. (2016). Ibu dalam Pemberian Imunisasi Dasar Pada Balita. Program Studi Pendidikan Bidan. Universitas Airlangga, Surabaya.

Ranuh Gede, Suyitno H, Hadinegoro S.R.S. Kartasasmita C.B. Ismoedijanto, et al (2011). Pedoman Imunisasi di Indonesia. Edisi keempat. IDAI.

WHO. (2015). Global Physical Activity Questionnaire (GPAQ): Analysis Guide. Geneva, World Health Organization.

WHO, (2012). Global Measles and Rubella Strategic Plan 2012-2020.

Ganeva Word Health Organization 